\title{
Sağlık Hizmetleri Meslek Yüksekokulu Öğrencilerinin İş Doyumları ve Etkileyen Faktörler
}

\author{
Job Satisfaction and Effecting Factors of Health Services Vocational School Students
}

Asu GÜRER ${ }^{*}$, Fidan KÜDÜR*, Albena GAYEF**, Mert BARUT**, Emel İÇLI' ${ }^{* * * *}$

\section{ÖZ}

Bir toplumun sağlıkl, mutlu ve üretken olmasının, o toplumun üyelerinin çalışmayaşamlarındaüst düzeyde doyumalmalarıileilişkiliolduğuaçıktır. Bu araştırmanın amacı Marmara Üniversitesi Sağlık Hizmetleri Meslek Yüksekokulu Anestezi Programı'nda öğrenim gören, aynı zamanda devlet ve özel sektörde Anestezi Teknisyeni olarak çalışan öğrencilerin iş doyumlarını ve etkileyen faktörleri belirlemektir. Araştırma, Şubat 2012'de Marmara Üniversitesi Sağlık Hizmetleri Meslek Yüksekokulu Anestezi Programı 1.ve 2.sınıf, I.ve II. öğretim öğrencileri ile ( $\mathrm{n}=120)$ yapılmıştır. Verilerin analizi SPSS for Windows 17.0 programı kullanılarak yapılmıştır. Öğrencilerin yaşına göre yöneticilik/liderlik alt boyutu açısından ve cinsiyetine göre genel kalite boyutu açısından anlamlı bir fark tespit edilmiştir $(\mathrm{p}<0,05)$. Öğrencilerin öğrenim gördükleri sınıfa göre kurumsal politika ve stratejiler alt boyutuna göre 2 sınıf I.öğretim puan ortalamalarının 1.sınıf II.öğretim öğrencilerinden yüksek olduğu tespit edilmiştir. Kendini gerçekleştirme ve kişilerarası iletişim alt boyutlarına göre 2 .sınıf I.öğretim öğrencilerinin puan ortalamaları 1.sınıf I. Öğretim ve II.öğretim, 2.sınıf II.öğretim öğrencilerinden yüksek bulunmuştur. Genel kalite, lojistik ve gelişim olanakları alt boyutları ile ölçek toplam açısından 2.sınıf I.öğretim öğrencilerinin puan ortalamaları 1.sınıf I. Öğretim ve II.öğretim öğrencilerinden yüksek olduğu tespit edilmiştir $(\mathrm{p}<0,05)$. Öğrencilerin meslek tercih etme nedeni açısından kurumsal politika ve stratejiler, kendini gerçekleştirme, genel kalite, lojistik ve gelişim olanakları alt boyutları açısından anlamlı bir fark saptanmıştır $(\mathrm{p}<0,05)$. Araştırma sonucunda, iş doyum ölçeği toplam puan ortalaması 77,14+ 20,72 (Min:37 - Max:132) olarak saptanmıştır. Anestezi teknisyenlerinin iş doyumunu, buna bağlı olarak da iş verimini ve hizmetin kalitesini arttırmak amacıyla her alanda motive edilmeleri gerektiği düşünülmektedir.

Anahtar Kelimeler: Anestezi teknisyeni, iş doyumu, iş verimi

\footnotetext{
Asu GÜRER (四)

"Marmara Üniversitesi Sağllk Hizmetleri Meslek Yüksekokulu Anestezi Programi

${ }^{* *}$ Tip Ĕ̈itimcisi

*** İstanbul Üniversitesi Florence Nightingale Hemşirelik Fakültesi Ögrencisi

***** Marmara Üniversitesi Sağllk Hizmetleri Meslek Yüksekokulu Emekli Öğretim Görevlisi

e-posta:asu.gurer@marmara.edu.tr
}

\begin{abstract}
It is clear that a society being healthy, happy and productive is associated with the highest satisfaction in the working life of its members. The aim of this research is to determine the job satisfaction and the factors affecting the students who are studying at the Anesthesia Department of the Marmara University Vocational School of Health Services and at the same time working as an Anesthesia Technician in the state and private sector. The research was carried out in February 2012 at Marmara University Vocational School of Health Services, Department of Anesthesia first education and second education first and second class students $(n=120)$. SPSS for Windows 17.0 program was used for analyzes. A significant difference was found in terms of managerial / leadership subscale according to age and a in terms of general quality subscale according to the gender $(\mathrm{p}<0,05)$. There was a significant difference in terms of organizational policies and strategies, self-realization, general quality, interpersonal communication, managerial / leadership, logistics and development possibilities according to the classes in which students were educated $(\mathrm{p}<0,05)$. There was a significant difference in terms of organizational policy and strategies, self-realization, general quality, logistics and development possibilities in terms of the reasons of students choosing profession $(\mathrm{p}<0,05)$. The total score of the job satisfaction scale was 77,14 + 20,72 (Min: 37 - Max: 132). It is thought that anesthesia technicians should be motivated in every area in order to increase job satisfaction and quality of service and work efficiency accordingly.
\end{abstract}

Keywords: Anesthesia technician, job satisfaction, job efficiency

\section{GİRIŞ}

İnsan, günlük yaşamının önemli bir kısmını işinde geçirmektedir. İş yalnızca ekonomik açıdan değil, psikolojik açıdan da bireyin dünyasında önemli bir işleve sahiptir (1). İş doyumu, çalışanların sahip oldukları işteki rollerine karşı gösterdikleri duygusal tepkilerdir. İşe karşı gösterilen 
pozitif (olumlu) tepki iş doyumu, negatif (olumsuz) tepki ise iş doyumsuzluğu olarak adlandırılabilir $(2,3)$.

Bir toplumun daha sağlıklı, mutlu ve üretken olmasının, o toplumun üyelerinin çalışma yaşamlarında üst düzeyde doyum almaları ile ilişkili olduğu açıktır. Böylelikle yaşamın 1/3'ünden fazlasını dolduran bir iş yaşantısından, insanların almaları gereken doyumun önemi ortaya çıkmaktadır (4). İş memnuniyeti büyük ölçüde profesyonel özerklik, daha fazla çevre uyumu, sağlık hizmetlerinde devamlılık ve etkililik ile ilişkilidir (5). Çekmecelioğlu'na göre iş doyumu çalışanın normlar, değerler ve beklentiler sisteminden geçerek değerlendirilen iş ve iş koşullarına ilişkin algılarına karşı geliştirdiği tepkilerden oluşmaktadır (6).

İş yerinde gerçekleştirdiği uğraşın çalışana anlamsız gelmesi ve onu tatmin etmemesi, yaşanılan sorunların yönetim tarafından uygun biçimde ele alınmaması gibi sebeplerle çalışan kendini iş yerinden uzak tutmakta ve bezginlik belirtisi göstermektedir. Beklentilerine ulaşamayan çalışan kendisinden beklenilmeyen davranış şekilleri sergileyebilmekte, bazen de saldırgan olabilmektedir (7).

Çalışan bireylerin iş doyum düzeyini etkileyen etkenler iki ana grupta toplanarak incelenebilir.

\section{Bireysel özellikler}

\section{2.Çevresel ya da örgütsel özellikler (8)}

Konu ile ilgili literatürde, iş doyumu etkeni olarak en çok sözü edilen bireysel özellikler: yaş, cinsiyet, eğitim düzeyi, meslek, statü, sosyo-kültürel çevre, zeka, kişilik, genel yaşam tutumları ve aynı işte geçirilen süredir (8).

Çevresel faktörler olarak, işin gerektirdiği beceri çeşitliliği, işle özdeşleşme, işin önemi, otonomi, geri bildirim, ücret, fiziksel çalışma koşulları, terfi koşulları, üstlerle ilişkiler, çalışma arkadaşlarıyla ilişkiler, iş güvenliği, yaratıcılık gibi faktörler sayılabilir $(9,10)$.

İş doyumu ölçeği alt boyutları:

a) Kurumsal politika ve stratejiler: Kurumsal politika ve startejilerde alınan ücret, görev tanımlarındaki netlik, yükselme olanakları çalışana sağlanan iş güvencesi ve üst yönetim ile çalışanlar arasındaki iletişim önemlidir (11).

b) Kendini gerçekleştirme: İşin çalışanın yeteneklerini kullanmaya elverişli olması, yenilikleri öğrenmeye ve gelişmeye olanaklı olması iş doyumunu arttıran etkenlerdir. Bunun yanında çalışanı yaratıcılığa, değişikliğe ve sorumluluk almaya yönlendirmesi ve yapılan işin sorun çözmeye dayanması, çalışanın kendisini ispatlayabileceği alanların sağlanması iş doyumunu arttırmaktadir (12).

c) Çalışma yaşamının genel kalitesi: Genel olarak çalışana kurum tarafından sağlanan sosyal olanaklar ve fiziksel şartlar çalışma yaşamının genel kalitesini oluşturur. Yapılan çalışmalar fiziksel ve sosyal olanakların iş doyumu üzerine etkisi olduğunu göstermektedir (13).

d) Kişilerarası iletişim: Kurumlarda görülen ilişkiler çoğunlukla karş1lıklı hizmet temeline dayanan işlevsel ilişkilerdir. Bu tür ilişkide her ilişki karşılıklı yapılan hizmete, yardıma ve dayanışmaya dayanır. Bu ilişkilerin iyi olması çalışana işinde doyum sağlar.

e) Yöneticilik/ Liderlik: Çalışılan birimlerde yönetici ve yöneticilerin niteliği, iş doyumunda önemlidir. Ekip çalışmasına uygun, çalışanların kararlara katılmasına izin veren, üst yönetim ile iletişim kurabilen, sorunlar için çözüm önerileri getirilen, terfilerin adaletli bir şekilde gerçekleştiği kurumlarda çalışanların daha fazla iş doyumuna sahip oldukları bulunmuştur.

Konu insan sağlığı olduğunda sağlık çalışanlarında iş doyumunun önemi daha da artmaktadır. Hasta ile bire bir iletişimde olan anestezi teknikerlerinin verimli ve etkili hizmet sunabilmeleri için iş beklentilerinin bilinmesi ve gerekli girişimlerin yapılarak iş doyumu sağlandığının tespit edilmesi gerekmektedir. İş doyumunun sağlanabilmesi ölçekte de belirtildiği üzere çok yönlü değerlendirilmesi gerekir. Yapılacak bu girişimler sayesinde sağlık çalışanının iş doyumunun artırılması, hasta memnuniyeti ve sağlıkta kalite olarak geri dönecektir.

Aynı zamanda iş doyumsuzluğunun, uğraşla ilgili kendine güvende azalma, iş veriminde azalma, işe devamsızlık, tükenme sendromu, işi bırakma, sigara, alkol, ilaç alışkanlığı, aile içi ilişkilerde bozulma, kişiler arası iletişim sorunları gibi mesleki ve sosyal sorunlara neden olduğu görülmüştür $(14,15)$. Bu durum hem hasta hem de sağlık çalışanı ve dolayısı ile ekibi de doğrudan etkilemektedir.

İş doyumu ve iş doyumunu etkileyen faktörlerle ilgili olarak literatürde yapılmış olan çalışmalar ışığında bu araştırmanın amacı, Sağlık Hizmetleri Meslek Yüksekokulu Anestezi Programı'nda öğrenim görmekte olan, aynı zamanda devlet sektörü ve özel sektörde Anestezi Teknisyeni olarak çalışan öğrencilerin iş doyumlarını ve etkileyen faktörleri ortaya çıkarmak olarak belirlenmiştir. 


\section{GEREÇ ve YÖNTEM}

Bu araştırma, Şubat 2012'de Marmara Üniversitesi Sağlık Hizmetleri Meslek Yüksekokulu Anestezi Programı 1. ve 2. sinıf, I. ve II. öğretim öğrencileri üzerinde $(n=120)$ yapılmıştır. Bu araştırmada veri toplama aracı olarak Türköz (1997) tarafından, geçerliği ve güvenirliği gösterilmiş ölçeklerden yararlanılarak geliştirilmiş olan 32 maddelik iş doyum ölçeği kullanılmıştır. İş doyum ölçeği Beşli likert tarzında toplam 7 alt boyuttan oluşmaktadır. Bu alt boyutlar ve maddeleri; kurumsal politika ve stratejiler (6, $7,10,11,13,14,15,20,21,27,29)$, kendini gerçekleştirme $(9,12,22,23,24,25,26)$, genel kalite $(17,18,9,31,32)$, kişilerarası iletişim $(1,2,30)$, yöneticilik/ liderlik $(3,4)$, lojistik ve gelişim olanakları $(5,8,16)$, sağlık güvencesi (28). Çalışmamızda chronbach alpha değeri 0,84 olarak saptanmıştır.

Verilerin analizi SPSS for Windows 17.0 program1 kullanılarak yapılmıştır. Araştırma verilerinin analizinde sıklık dağılımları, t-testi, tek yönlü varyans analizi kullanılmıştır. Çalışmamızda bağımsız değişkenlere (cinsiyet, yaş, medeni durum, sınıfi, mezun olduğu ortaöğretim kurumu türü, kaç yıldır anestezi teknisyeni olarak çalıştığı, mesleği tercih etme nedeni, görev yapmakta olduğu birimi, birimdeki çalı̧̧ma süresi, birimdeki çalışma nedeni) göre ölçeğin alt boyutları açısından öğrenciler arasında istatistiksel olarak farklılık olup olmadığını belirlemek amacıyla, t-testi, tek yönlü varyans analizi yapılmıştır.

\section{BULGULAR}

Tablo 1'de görüldüğü gibi Anestezi Programı öğrencilerinin $\% 79,2$ 'sinin kadın, \%75'i 18-20 yaş grubunda, \%99,2'sinin bekar, \%30'unun 1.sınıf I.öğretim, \%25'inin 1.sınıf II.öğretim, \%23,3'ünün 2.sinıf I.öğretim, \%21,7'sinin 2.sınıf II. öğretim öğrencisi olduğu, \%99,2'inin sağl1k meslek lisesi mezunu, \%50,8'i bir yıldan az süredir anestezi teknisyeni olarak çalışmakta, \%45,8'inin mezun olunduğunda iş bulma kolaylığı olduğu için \%20,8'inin mesleği kendisine yakın hissettiği, \%19,2'sinin ailesinin isteği ile Anestezi Programı'nı tercih ettiği, \%45,8'inin mesleği tekrar seçme isteğinde olduğu, \%78,3'ünün ameliyathanede görev aldığı̆, $\% 56,7$ 'sinin bir yıldan az süredir aynı birimde çalıştı̆̆ $\% 67,5$ 'inin kendi isteği ile bu birimde çalıştı̆̆ $\% 55,8$ 'inin birim değiştirmek istemediği saptanmıştır.
Tablo 1: Anestezi Programı Öğrencilerinin Demografik Özellikleri $(\mathrm{n}=120)$

\begin{tabular}{|c|c|c|}
\hline & $\mathbf{n}$ & $\%$ \\
\hline \multicolumn{3}{|l|}{ Cinsiyet } \\
\hline $\mathrm{K} 1 \mathrm{Z}$ & 95 & 79,2 \\
\hline Erkek & 25 & 20,8 \\
\hline \multicolumn{3}{|l|}{ Yaş } \\
\hline$<18$ & 19 & 15,8 \\
\hline $18-20$ & 90 & 75 \\
\hline$>20$ & 11 & 9,2 \\
\hline \multicolumn{3}{|l|}{ Medeni Durum } \\
\hline Bekar & 119 & 99,2 \\
\hline Evli & 1 &, 8 \\
\hline \multicolumn{3}{|l|}{ Sinıfi } \\
\hline 1.sinıf I.öğretim & 36 & 30 \\
\hline 1sınıf II.öğretim & 30 & 25 \\
\hline 2.sınıf I.öğretim & 28 & 23,3 \\
\hline 2.sınıf II.öğretim & 26 & 21,7 \\
\hline \multicolumn{3}{|l|}{ Mezun olunan ortaöğretim kurum türü } \\
\hline Sağlık Meslek Lisesi & 119 & 99,2 \\
\hline Diğer & 1 & 8 \\
\hline \multicolumn{3}{|c|}{ Anestezi teknisyeni olarak çalışma süresi } \\
\hline 1 y1ldan az & 61 & 50,8 \\
\hline $1-5$ y1l & 58 & 48,3 \\
\hline$>5 \mathrm{y} 1 \mathrm{l}$ & 1 &, 8 \\
\hline \multicolumn{3}{|l|}{ Meslek tercih nedeni } \\
\hline Mezun olduğunda iş bulma kolaylığ 1 & 55 & 45,8 \\
\hline Aile isteği & 23 & 19,2 \\
\hline Mesleği kendine yakın hissetme & 25 & 20,8 \\
\hline Diğer & 17 & 14,2 \\
\hline \multicolumn{3}{|l|}{ Mesleği tekrar seçme isteği } \\
\hline Evet & 55 & 45,8 \\
\hline Hayır & 28 & 23,3 \\
\hline Kararsızım & 37 & 30,8 \\
\hline \multicolumn{3}{|l|}{ Görev yaptığı birim } \\
\hline Ameliyathane & 94 & 78,3 \\
\hline Acil servis & 6 & 5 \\
\hline Yoğun bakım & 6 & 5 \\
\hline Servis & 3 & 2,5 \\
\hline Diğer & 11 & 9,2 \\
\hline \multicolumn{3}{|l|}{ Birimde çalışma süresi } \\
\hline$<1 \mathrm{y} 1 \mathrm{l}$ & 68 & 56,7 \\
\hline $1-5$ y1l aras1 & 52 & 43,3 \\
\hline \multicolumn{3}{|l|}{ Birimde çalışma nedeni } \\
\hline Kendi isteği & 81 & 67,5 \\
\hline Kurum ihtiyac1 & 23 & 19,2 \\
\hline Diğer & 16 & 13,3 \\
\hline \multicolumn{3}{|l|}{ Birim değiştirme isteği } \\
\hline Evet & 40 & 33,3 \\
\hline Hayır & 67 & 55,8 \\
\hline Kararsız & 13 & 10,8 \\
\hline TOPLAM & 120 & 100 \\
\hline
\end{tabular}


Öğrencilerin İş Doyum Ölçeği Alt Boyut ve Toplam Puanları Tablo 2'de verilmiştir. Öğrencilerin iş doyum ölçeği toplam puan ortalamaları 77.14 $\pm 20,72$ (Min:37 Max:132) olarak bulunmuştur. İş doyum ölçeği alt boyut puan ortalamalarının 1-53 arasında değiştiği, öğrencilerin iş doyum ölçeği kurumsal politika ve stratejiler alt boyut puan ortalaması $28,90 \pm 8,13$, kendini gerçekleştirme alt boyut puan ortalamasi $16,34 \pm 5,15$, genel kalite alt boyut puan ortalaması $11,17 \pm 3,51$, kişilerarası iletişim alt boyut puan ortalaması $6,29 \pm 2,12$, yöneticilik/liderlik alt boyut puan ortalaması 4,60 $\pm 2,15$, lojistik ve gelişim olanakları alt boyut puan ortalaması 7,39 $\pm 2,34$, sağlık güvencesi alt boyut puan ortalaması $2,42 \pm 1,08$ olduğu saptanmıştır.

Tablo 2: Öğrencilerin İş Doyum Ölçeği Alt Boyut Puanları ve Toplam Puanlar1

\begin{tabular}{|l|l|l|l|l|}
\hline İş doyumu alt boyutları & $\overline{\mathbf{X}}$ & SS & Min & Max \\
\hline Kurumsal politika ve stratejiler & 28,90 & 8,13 & 11,00 & 53,00 \\
\hline Kendini gerçekleştirme & 16,34 & 5,15 & 7,00 & 31,00 \\
\hline Genel kalite & 11,17 & 3,51 & 5,00 & 21,00 \\
\hline Kişilerarası iletişim & 6,29 & 2,12 & 3,00 & 13,00 \\
\hline Yöneticilik/liderlik & 4,60 & 2,15 & 2,00 & 10,00 \\
\hline Lojistik ve gelişim olanakları & 7,39 & 2,34 & 3,00 & 15,00 \\
\hline Sağlık güvencesi & 2,42 & 1,08 & 1,00 & 5,00 \\
\hline Toplam & 77,14 & 20,72 & 37,00 & 132,00 \\
\hline
\end{tabular}

Öğrencilerin cinsiyetlerine göre iş doyumu ölçeği alt ve toplam puanlarının karşılaştırılması Tablo 3'de gösterilmiştir. Öğrencilerin cinsiyetlerine göre iş doyumu ölçeği alt boyutlarından genel kalite alt boyut puanları arasında istatistiksel olarak anlamlı bir fark bulunmuştur $(p<0,05)$. Genel kalite alt boyutu açısından kız öğrenciler erkek öğrencilere göre daha yüksek iş doyum puanına sahiptir. Cinsiyet açısından diğer alt ölçek puanları arasında anlamlı fark saptanmamıştır $(\mathrm{p}>0,05)$.
Tablo 3: Öğrencilerin Cinsiyetlerine Göre İş Doyumu Ölçeği Alt ve Toplam Puanlarının Karşılaştırılması (n=120)

\begin{tabular}{|l|l|l|l|l|}
\hline \multirow{2}{*}{$\begin{array}{l}\text { İş doyumu } \\
\text { alt boyutları }\end{array}$} & $\begin{array}{l}\text { Cinsiyet } \\
(\mathrm{n}=95) \\
\overline{\mathrm{x}} \pm \mathrm{ss}\end{array}$ & $\begin{array}{l}\text { Erkek }(\mathrm{n}=25) \\
\overline{\mathrm{x}} \pm \mathrm{ss}\end{array}$ & $\mathbf{t}$ & $\mathbf{p}$ \\
\hline $\begin{array}{l}\text { Kurumsal politika ve } \\
\text { stratejiler }\end{array}$ & $29,30 \pm 8,25$ & $27,40 \pm 7,62$ & 1,04 & 0,30 \\
\hline Kendini gerçekleştirme & $16,73 \pm 4,97$ & $14,84 \pm 5,65$ & 1,64 & 0,10 \\
\hline Genel kalite & $11,50 \pm 3,48$ & $9,92 \pm 3,40$ & 2,03 & $0,04 *$ \\
\hline Kişilerarası iletişim & $6,33 \pm 2,01$ & $6,12 \pm 2,52$ & 0,45 & 0,65 \\
\hline Yöneticilik/liderlik & $4,69 \pm 2,07$ & $4,28 \pm 2,42$ & 0,85 & 0,39 \\
\hline $\begin{array}{l}\text { Lojistik ve gelişim } \\
\text { olanakları }\end{array}$ & $7,52 \pm 2,40$ & $6,88 \pm 2,04$ & 1,23 & 0,22 \\
\hline Sağlik güvencesi & $2,40 \pm 1,04$ & $2,52 \pm 1,26$ & 0,48 & 0,62 \\
\hline Toplam & $78,50 \pm 20,61$ & $71,96 \pm 20,72$ & 1,41 & 0,16 \\
\hline
\end{tabular}

$*_{\mathrm{p}}<0,05$

Anestezi Programı öğrencilerinin iş doyum ölçek alt boyutlarından kurumsal politika ve stratejiler alt boyut puan ortalamaları sınıfına göre karşılaştıııldığında, 2.sınıf I.öğretim ile 1. Sınıf II.öğretim arasında istatistiksel olarak anlamlı farklılık saptanmıştır $(\mathrm{p}<0.05)$. Buna göre 2. Sınıf I. öğretim öğrencilerinin kurumsal politika ve stratejiler puan ortalamasının 1.sınıf II. öğretim öğrencilerinden daha yüksek olduğu tespit edilmiştir (Tablo 4).

Kendini gerçekleştirme alt boyut ortalamaları sınıflara göre karşılaştırıldığında 2.sınıf I.öğretim ile 1.sınıf I. öğretim ve II.öğretim, 2.sınıf II.öğretim arasında istatistiksel olarak anlamlı farkl11ık saptanmıştır $(\mathrm{p}<0.05)$. Bu durumda 2. sınıf I. öğretim öğrencilerinin kendini gerçekleştirme puan ortalamasının diğer sınıf öğrencilerinden daha yüksek olduğu tespit edilmiştir (Tablo 4).

Genel kalite alt boyut ortalamaları sinıflara göre karşılaştırıldığında 2.sınıf I.öğretim ile 1.sınıf I. öğretim ve II.öğretim arasında istatistiksel olarak anlamlı farklılık saptanmıştır $(\mathrm{p}<0.05)$. Bu durumda 2. sınıf I. öğretim öğrencilerinin kendini gerçekleştirme puan ortalamasının 1.sınıf I.öğretim ve II. öğretim öğrencilerinden daha yüksek olduğu tespit edilmiştir (Tablo 4). 
Tablo 4: Öğrencilerin Öğrenim Gördükleri Sınıfa Göre İş Doyumu Ölçeği Alt Boyut ve Toplam Puanlarının Karşıllaştırılması (n=120)

\begin{tabular}{|c|c|c|c|c|c|}
\hline Karşılaştırılan İş Doyum Ölçek Alt Boyutu & Sinif & & Ortalamalar Farkı & $\mathbf{p}$ & $\mathbf{F}$ \\
\hline \multirow{3}{*}{ Kurumsal Politika ve Stratejiler } & \multirow{3}{*}{$\begin{array}{l}\text { 2.sinıf } \\
\text { I. öğretim }\end{array}$} & 1.sınıf I.öğretim & $4,91 \pm 1,90$ & 0,053 & \multirow{3}{*}{7,405} \\
\hline & & 1.sınıf II.öğretim & $9,35 \pm 1,98$ & $0,000^{*}$ & \\
\hline & & 2.sınıf II.öğretim & $4,75 \pm 2,05$ & 0,102 & \\
\hline \multirow{3}{*}{ Kendini Gerçekleştirme } & \multirow{3}{*}{$\begin{array}{l}\text { 2.sınıf } \\
\text { I. öğretim }\end{array}$} & 1.sınıf I.öğretim & $3,15 \pm 1,20$ & $0,048^{*}$ & \multirow{3}{*}{7,574} \\
\hline & & 1.sınıf II.öğretim & $5,93 \pm 1,25$ & $0,000^{*}$ & \\
\hline & & 2.sınıf II.öğretim & $3,68 \pm 1,30$ & $0,27 *$ & \\
\hline \multirow{3}{*}{ Genel Kalite } & \multirow{3}{*}{$\begin{array}{l}\text { 2.sinıf } \\
\text { I. öğretim }\end{array}$} & 1.sınıf I.öğretim & $2,53 \pm 0,83$ & $0,016^{*}$ & \multirow{3}{*}{5,450} \\
\hline & & 1.sınıf II.öğretim & $3,37 \pm 0,87$ & $0,001^{*}$ & \\
\hline & & 2.sınıf II.öğretim & $1,68 \pm 0,90$ & 0,254 & \\
\hline \multirow{3}{*}{ Kişilerarası İletişim } & \multirow{3}{*}{$\begin{array}{l}\text { 2.sınıf } \\
\text { I. öğretim }\end{array}$} & 1.sinıf I.öğretim & $2,06 \pm 0,50$ & $0,000 *$ & \multirow{3}{*}{6,268} \\
\hline & & 1.sinıf II.öğretim & $1,74 \pm 0,52$ & $0,006^{*}$ & \\
\hline & & 2.sınıf II.öğretim & $1,52 \pm 0,54$ & $0,030^{*}$ & \\
\hline \multirow{3}{*}{ Yöneticilik ve Liderlik } & \multirow{3}{*}{$\begin{array}{l}\text { 2.sinıf } \\
\text { I. öğretim }\end{array}$} & 1.sınıf I.öğretim & $0,33 \pm 0,53$ & 0,923 & \multirow{3}{*}{2,778} \\
\hline & & 1.sınıf II.öğretim & $1,30 \pm 0,55$ & 0,093 & \\
\hline & & 2.sınıf II.öğretim & $0,15 \pm 057$ & 0,993 & \\
\hline \multirow{3}{*}{ Lojistik ve Gelişim Olanakları } & \multirow{3}{*}{$\begin{array}{l}\text { 2.sınıf } \\
\text { I. öğretim }\end{array}$} & 1.sınıf I.öğretim & $1,63 \pm 0,56$ & $0,022 *$ & \multirow{3}{*}{5,156} \\
\hline & & 1.sınıf II.öğretim & $2,21 \pm 0,58$ & $0,001^{*}$ & \\
\hline & & 2.sınıf II.öğretim & $1,44 \pm 0,60$ & 0,087 & \\
\hline \multirow{3}{*}{ Sağlık Güvencesi } & \multirow{3}{*}{$\begin{array}{l}\text { 2.sinıf } \\
\text { I. öğretim }\end{array}$} & 1.sınıf I.öğretim & $0,26 \pm 0,27$ & 0,769 & \multirow{3}{*}{0,784} \\
\hline & & 1.sınıf II.öğretim & $0,30 \pm 0,28$ & 0,714 & \\
\hline & & 2.sınıf II.öğretim & $0,04 \pm 0,29$ & 0,999 & \\
\hline \multirow{3}{*}{ Toplam } & \multirow{3}{*}{$\begin{array}{l}\text { 2.sınıf } \\
\text { I. öğretim }\end{array}$} & 1.sınıf I.öğretim & $14,90 \pm 4,92$ & $0,013^{*}$ & \multirow{3}{*}{7,859} \\
\hline & & 1.sınıf II.öğretim & $24,23 \pm 5,02$ & $0,000^{*}$ & \\
\hline & & 2.sınıf II.öğretim & $12,88 \pm 5,21$ & 0,070 & \\
\hline
\end{tabular}

$* \mathrm{p}<0,05$

Kişilerarası İletişim alt boyut ortalamaları sınıflara göre karşılaştırıldığında 2.sınıf I.öğretim ile 1.sınıf I. öğretim ve II.öğretim, 2.sınıf II.öğretim arasında istatistiksel olarak anlamlı farklılık saptanmıştır $(\mathrm{p}<0.05)$. Bu durumda 2 . sınıf I. öğretim öğrencilerinin kişilerarası iletişim puan ortalamasının diğer sınıf öğrencilerinden daha yüksek olduğu tespit edilmiştir (Tablo 4).

Lojistik ve gelişim olanakları alt boyut ortalamaları sınıflara göre karşılaştırıldığında 2.sınıf I.öğretim ile 1.sınıf I. öğretim ve II.öğretim arasında istatistiksel olarak anlamlı farklılık saptanmıştır $(\mathrm{p}<0.05)$. Bu durumda 2. sınıf I. öğretim öğrencilerinin lojistik ve gelişim olanakları puan ortalamasının 1.sınıf I. öğretim ve II.öğretim sınıf öğrencilerinden daha yüksek olduğu tespit edilmiştir (Tablo 4).

Toplam alt boyut puan ortalamaları siniflara göre karşılaştırıldığında 2.sınıf I.öğretim ile 1.sınıf I. öğretim ve II.öğretim arasında istatistiksel olarak anlamlı farklılık saptanmıştır $(p<0.05)$. Bu durumda 2. sınıf I. öğretim öğrencilerinin toplam puan ortalamalarının 1.sınıf I. öğretim ve II.öğretim sınıf öğrencilerinden daha yüksek olduğu tespit edilmiştir (Tablo 4).
Tablo 5'de görüldüğü gibi Anestezi Programı öğrencilerinin iş doyum ölçek alt boyutlarından kendini gerçekleştirme alt boyut puan ortalamaları meslek tercih nedenine göre karşılaştırıldığında, ailemin isteği seçeneği ile mesleği kendime yakın hissetmem seçeneği arasında istatistiksel olarak anlamlı farklılık saptanmıştır $(p<0.05)$. Buna göre mesleği ailesinin isteği ile tercih eden öğrencilerin kendini gerçekleştirme puan ortalamasının mesleği kendine yakın hissederek tercih yapan öğrencilerin kendini gerçekleştirme puan ortalamasına göre daha yüksek olduğu tespit edilmiştir (Tablo 5).

Öğrencilerin iş doyum ölçek alt boyutlarından genel kalite alt boyut puan ortalamaları meslek tercih nedenine göre karşılaştırıldığında, ailemin isteği seçeneği ile mezun olduğumda iş bulma kolaylığ 1 seçeneği ve mesleği kendisine yakın hissetme seçeneği arasında istatistiksel olarak anlamlı farklılık saptanmıştır $(\mathrm{p}<0.05)$. Buna göre mesleği ailesinin isteği ile tercih eden öğrencilerin genel kalite boyutu puan ortalamasının mezun olduğunda iş bulma kolaylığı nedeni ile tercih yapan öğrencilerin genel kalite boyutu puan ortalamasına ve mesleği kendisine yakın hisseden öğrencilerin genel kalite puan ortalamasına göre daha yüksek olduğu tespit edilmiştir (Tablo 5). 
Tablo 5: Meslek Tercih Nedenine Göre İş Doyumu Ölçeği Alt Boyut ve Toplam Puanlarının Karşılaştırılması (n=120)

\begin{tabular}{|c|c|c|c|c|c|}
\hline $\begin{array}{l}\text { Karşılaş̧ırılan İş Doyum Ölçek Alt } \\
\text { Boyutu }\end{array}$ & \multicolumn{2}{|c|}{ Meslek tercih nedeni } & $\begin{array}{l}\text { Ortalamalar } \\
\text { Farkı }\end{array}$ & p & $\mathbf{F}$ \\
\hline \multirow{3}{*}{ Kendini gerçekleştirme } & \multirow{3}{*}{ Ailemin isteği } & Mezun olduğumda iş bulma kolaylığ 1 & 2,29960 & 0,246 & \multirow{3}{*}{4,327} \\
\hline & & Mesleği kendime yakın hissetmem & 4,96870 & $0,004 *$ & \\
\hline & & Diğer & 1,25575 & 0,857 & \\
\hline \multirow{3}{*}{ Genel kalite } & \multirow{3}{*}{ Ailemin isteği } & Mezun olduğumda iş bulma kolaylığ 1 & 2,42451 & $0,019^{*}$ & \multirow{3}{*}{6,637} \\
\hline & & Mesleği kendime yakın hissetmem & 3,98087 & $0,000^{*}$ & \\
\hline & & Diğer & 1,02258 & 0,764 & \\
\hline \multirow{3}{*}{ Lojistik ve gelişim olanakları } & \multirow{3}{*}{ Diğer } & Mezun olduğumda iş bulma kolaylığ 1 & 0,89840 & 0,487 & \multirow{3}{*}{3,390} \\
\hline & & Mesleği kendime yakın hissetmem & 2,11294 & $0,020^{*}$ & \\
\hline & & Ailemin isteği & 0,57033 & 0,862 & \\
\hline \multirow{3}{*}{ Toplam } & \multirow{3}{*}{ Ailemin isteği } & Mezun olduğumda iş bulma kolaylığ & 10,22609 & 0,171 & \multirow{3}{*}{4,136} \\
\hline & & Mesleği kendime yakın hissetmem & 18,10609 & $0,011^{*}$ & \\
\hline & & Diğer & 1,59079 & 0,995 & \\
\hline
\end{tabular}

${ }^{*} p<0,05$

Öğrencilerin iş doyum ölçek alt boyutlarından lojistik ve gelişim olanakları alt boyut puan ortalamaları meslek tercih nedenine göre karşılaştırıldığında, diğer seçeneği ile mesleği kendime yakın hissetmem seçeneği arasında istatistiksel olarak anlamlı farklılık saptanmıştır $(\mathrm{p}<0.05)$. Buna göre mesleği diğer faktörler nedeni ile tercih eden öğrencilerin lojistik ve gelişim olanakları alt boyut puan ortalamasının mesleği kendine yakın hissederek tercih yapan öğrencilerin lojistik ve gelişim olanakları puan ortalamasına göre daha yüksek olduğu tespit edilmiştir (Tablo 5).

Öğrencilerin iş doyum ölçek toplam puan ortalamaları meslek tercih nedenine göre karşılaştırıldığında, ailemin isteği seçeneği ile mesleği kendime yakın hissetmem seçeneği arasında istatistiksel olarak anlamlı farklılık saptanmıştır $(p<0.05)$. Buna göre mesleği ailesinin isteği ile tercih eden öğrencilerin toplam puan ortalamasının mesleği kendine yakın hissederek tercih yapan öğrencilerin toplam puan ortalamasına göre daha yüksek olduğu tespit edilmiştir (Tablo 5).

\section{TARTISYMA}

Yapılan bir çalışmada iş doyumunu etkileyen faktörlerin önem sırasıyla; işten hoşlanma, çalışma koşulları, ücret, işe karşı hassasiyet, yönetim ve denetim anlayışı, alt-üst ilişkisi ve çalışma hakları olduğu bulgulanmıştır (16).

Aynı türde, özellikle depek fazla uzmanlık gerektirmeyen, çok kolay öğrenilebilen ve sürekli tekrarlanan becerilerin kullanıldığı işlerde çalışanlar genellikle işlerinden daha az doyum almaktadırlar (17). İşin yürütülmesi sırasında bilgi ve beceriler kazanma, mevcut bilgi ve yetenekleri kullanma olanağı, işin çesitliliği, otonomi, işi yapma ile duyulan başarı hissi, istenilen düzeyde iş yükü, işin toplum içindeki saygınlığı, işin gerektirdikleri (dikkat, yaratıcılık, kurum dışında çalışma, sağlıklı bireye hizmet sunma) gibi boyutlar iş doyumu üzerinde etkilidir (9). Çalışan yaptığı işi ne kadar önemsiyor ve iş başkalarının yaşamı üzerinde ne derece olumlu yönde etkide bulunuyorsa, çalışanın işinden o derece doyum alacağı varsayılmaktadır. (17).

Bir çalışanın işin nasıl yapılacağına dair karar verme özgürlüğü (otonomi) ne kadar fazlaysa, çalışan işinden o kadar doyum almaktadır. Eğer kişi çalışma saatlerine kendisi karar verebiliyor, çalışma yöntemlerini kendisi seçebiliyor, yapılacak işlerin sırasına kendi karar verebiliyorsa işteki otonomisinin yüksek olduğu kabul edilmektedir $(17,18)$

Çalışana geribildirim verilmesi, başka bir deyişle yaptığı iş konusunda bilgilendirilmesi, performansını daha iyiye götürebilmesi ve varsa hatalarını düzeltmesi için gereklidir (17). Ücretin iş doyumuyla yakından ilişkili olduğu ileri sürülmektedir. Düşük ücret, çalışanların işleriyle ilgili olarak ifade ettikleri en önemli doyumsuzluk kaynağıdır (1, 17, 19, 20).

Aşırı gürültü, yüksek ya da düşük 1sı, aşırı beden gücü kullanımı, tehlikeli çalışma koşulları en fazla doyumsuzluk yaratan fiziksel çalışma koşulları arasındadır. Bunun nedeni bu tür olumsuz koşulların aynı zamanda stresin ortaya çıkardığı vücut tepkilerine, yaşanan gerginliğin de iş doyumsuzluğuna yol açmasıdır (17).

Terfi, işten elde edilen maddi geliri artırdığı kadar, bireyin sosyal statüsünü yükseltir ve toplum içindeki yerini olumlu yönde değiştirir (20). Eğer bir işletmede terfiler adil 
bir sekilde yapılmıyorsa, haksızlığa uğramışlık duygusu çalışanın iş doyumunu azaltabilir Yöneticilerle kurulan ilişkinin niteliğinin çalışanın içinde bulunduğu duygusal durumu ve çalışma ortamında duyulan memnuniyeti etkileyeceği göz önüne alınmalıdır (17).

Çalışma arkadaşlarıyla kurulan destekleyici ilişkiler çalışanı işine bağlayan ve işinden doyum almasını sağlayan faktörlerden biridir (17). "İyi” bir çalışma ekibi işi daha çok hoşlanılabilir bir hale getirir $(1,20)$.

Bir yöneticinin çalışanlar arasında ayrımcılık yapması, özellikle iş yükü dağılımları, terfi, performans değerlendirmeleri gibi uygulamalarda adil davranmaması çalışanlar arasındaki ilişkinin bozulmasına ve birbirlerine güvensizlik duymalarına yol açmaktadır. Böyle bir durumda çalışanların iş doyumları azalmaktadır (17).

Hem sosyal hem de fiziksel açıdan güvenli bir iş ortamında çalışmak kişinin işiyle ilgili olarak hissettiği duygularının olumlu olmasına yol açarak iş doyumunu artırmaktadır (17).

İşin gerektirdiği ölçüde yaratıcılıklarını kullanmalarına uygun bir iş ortamında çalışan bireylerin daha fazla iş doyumu alarak, daha az işten ayrılma niyeti içinde olacakları bilinen bir gerçektir (17). Eğitim düzeyi ile iş doyumu arasındaki ilişki araştırıldığında, genellikle eğitim düzeyinin yükselmesi ve iş doyumu arasında negatif bir ilişki bulunmuştur. Daha esnek kişiliği olan, kendini ifade etme yeteneğine sahip ve ilişkilerinde yapıcı bireylerin daha yüksek iş doyumuna sahip oldukları rapor edilmiştir (21).

Araştırmamızdan elde edilmiş bulgular, Sağlık Hizmetleri Meslek Yüksekokulu Anestezi Programı'nda öğrenim görmekte olan aynı zamanda devlet sektörü ve özel sektörde Anestezi Teknisyeni olarak çalışan öğrencilerin iş doyumlarının en yüksek olduğu alt boyutlar, kurumsal politika ve stratejiler ile kendini gerçekleştirme alt boyutudur. Öğrencilerin genel kalite, lojistik ve gelişim olanakları ve kişilerarası iletişim alt boyutları puan ortalamalarına bakıldığında orta düzeyde doyumlu oldukları saptanmıştır. Güneş (13)'in hemşirelerin iş doyumu ile ilgili çalışmasında ise iş doyumu ölçeği alt boyutlarında en yüksek puanın yöneticilik/liderlik ve kişilerarası iletişim boyutlarında olduğu, kurumsal politika ve stratejiler, sağlık güvencesi, lojistik ve gelişme olanakları ile kendini gerçekleştirme alt boyutlarında doyum düzeyi ortanın altında olduğu gösterilmiştir.

Öğrencilerin cinsiyetlerine göre iş doyumu ölçeği alt boyutlarından genel kalite alt boyut puanları arasında istatistiksel olarak anlamlı bir fark bulunmuştur. Genel kalite alt boyutu açısından kız öğrenciler erkek öğrencilere göre daha yüksek iş doyum puanına sahiptir. Cinsiyet açısından diğer alt ölçek puanları arasında anlamlı fark saptanmamıştır. Buna karşılık, hekimler ile hemşirelerin iş doyumlarını belirlemek amacı ile yapılmış bir çalışmada, kadın hekimler ile erkek hekimler arasında iş doyum düzeyleri bakımından anlamlı farklılık olduğu tespit edilmiştir. Kadın hekimlerin içsel, dişsal ve genel iş doyum düzeylerinin, erkek hekimlerden anlamlı düzeyde düşük olduğu gösterilmiştir (13).

Araştırmamızda Anestezi Programı öğrencilerinin çalıştıkları birime göre iş doyumu toplam ve alt boyutları arasında anlamlı fark bulunmamıştır. Güneş (21)'in hemşirelerin iş doyumu ile ilgili çalışmasında ise hemşirelerin çalıştıkları birimlere göre iş doyumu toplam ve alt ölçek puanları arasında anlamlı fark saptanmıştır. Poliklinik ve gündüz çalışılan birimler ile ameliyathanede çalışan hemşirelerin toplam iş doyum puanının diğer birimlere göre daha yüksek olduğu gösterilmiştir.

Anestezi Programı öğrencilerinin iş doyum ölçek alt boyutlarından kendini gerçekleştirme alt boyut puan ortalamaları meslek tercih nedenine göre karşıllaştırıldığında, ailesinin isteği seçeneği ile mesleği kendime yakın hissetmem seçeneği arasında istatistiksel olarak anlamlı farklılık saptanmıştır. Buna göre mesleği ailesinin isteği ile tercih eden öğrencilerin puan ortalamasının mesleği kendine yakın hissederek tercih yapan öğrencilerin puan ortalamasına göre daha yüksek olduğu tespit edilmiştir. Öğrencilerin iş doyum ölçek toplam puan ortalamaları meslek tercih nedenine göre karşılaştırıldığında, ailemin isteği seçeneği ile mesleği kendime yakın hissetmem seçeneği arasında istatistiksel olarak anlamlı farklılık saptanmıştır. Buna göre mesleği ailesinin isteği ile tercih eden öğrencilerin puan ortalamasının mesleği kendine yakın hissederek tercih yapan öğrencilerin puan ortalamasına göre daha yüksek olduğu tespit edilmiştir. Bu durum, meslek seçiminde ailenin öğrenci üzerinde etkisinin yüksek olduğunu düşündürmektedir.

Yeterli iş doyum düzeyinin olması, iş görenin mutluluğunu artırmakla birlikte, işine bağlanması, verimli çalışması, firenin azalması, iş gücü devir oranının düşmesi gibi olumlu sonuçlara (22) yol açmakta, iş doyumsuzluğu ise ruhsal açıdan iş göreni olumsuz etkilemekte, yoğun ve sürekli kaygı yaratıp, bıkkınlık, işi bırakma, devamsızlık, kavgacılık gibi örgüt içi istenmeyen davranışlara yol açmaktadır (23). 
$\mathrm{Bu}$ nedenle sağlık çalışanları için (özellikle stres yoğunluğu yüksek ve iş doyumu düşük gruplar) kendini tanıma ve geliştirme, iş stresine neden olan stresörleri tanıma, stresle etkin baş etme yollarını kazandırma, problem çözme ve iletişim becerilerini geliştirmeye yönelik eğitim ve rehberlik programlarının oluşturulması, ayrıca her meslek grubunun sağlık hizmeti üretiminin planlanması, örgütlenmesi ve sunum aşamalarına doğrudan katılması ve her aşamada kendi alanı ile ilgili söz ve karar sahibi olması sağlanmalıdır (24).

İş doyumunun geniş bir konu olduğu unutulmadan, iş doyumu ile birlikte kuruma bağlılık, rol çatışması ve rol belirsizliği gibi tutumlar da belirli aralıklarla değerlendirilmeli, elde edilen sonuçlara göre gereken düzenlemeler yapılmalıdır (13).

Nöbet listesi ve hafta sonu izinleri uygun şekilde düzenlenmeli, mesleki gelişim ve yükselme olanakları ve kararlara katılımları sağlanmalı, yükseltmeler performansa dayalı olmalıdır. Rol çatışması ve rol belirsizliğinin iş doyumuna olumsuz etkisi olduğundan görev tanımları kesin bir şekilde belirlenmeli ve gerekli önlemler alınmalıdır. Kurum içerisinde tanınma, mesleki gelişim ve yükselme olanaklarının uygun şekilde planlanması, bilimsel toplantı ve kongrelere katılımının sağlanması da kuruma bağlılığ1 arttıracaktır.

İş doyumu ile ilgili araştırmalar daha geniş çaplı yapılarak dönemsel değişikliklerle izlenmelidir. Doyumsuzluk gösterilen konuların değerlendirilmesi, geri bildirimin yapılması, iş doyumunun ve bununla ilişkili olan yaşam doyumunun arttırılması için düzenlemeler yapılmalıdır.

\section{KAYNAKLAR}

1. Topçu ÖG. İş Doyumu ve Motivasyon: Havacılık Sektöründe Çalışan Pilotların İş Doyum Seviyelerinin Tespit Edilerek İzlenebilecek Alternatif Motivasyon Stratejilerinin Belirlenmesi Üzerine Bir Araştırma, Çukurova Üniversitesi Sosyal Bilimler Enstitüsü İşletme Anabilim Dalı, Yayımlanmamış Doktora Tezi. 2003.

2. Chen, Y. Relationships Among Service Orientation, Job Satisfaction and Organizational Commitment İn The İnternational Tourist Hotel İndustry. Journal of American Academy of Business. 2007, c.4, ss.24.

3. Yüksek SS. Türkiye Cumhuriyeti Çukurova Üniversitesi Sosyal Bilimler Enstitüsü İşletme Anabilim Dalı Örgütsel ve Bireysel Özellikler Açısından İş Doyumu İle Tükenmişlik Düzeyi Arasındaki İlişki: Alanya'da Banka Çalışanları Üzerinde Bir İnceleme. Lisans Tezi. 2011.
4. Çetin H, Zetter S.A, Taş S, Çaylak M. İş Doyumu ve Çalışanların Demografik Özellikleri Arasındaki İlişkilerin Belirlenmesi: Antalya Atatürk Devlet Hastanesi Örneği, Akdeniz İ.İ.B.F. Dergisi (26) 2013; 145-163.

5. Adams A ve Bond S. Hospital Nurses'Job Satisfaction, Individual and Organizationer Characteristics. Journal of Advanced Nursing, 2003; 2(3): 536 - 543.

6. Çekmecelioğlu H. İş Tatmini ve Örgütsel Bağlılık Tutumlarının İşten Ayrılma Niyeti ve Verimlilik Üzerindeki Etkilerinin Değerlendirilmesi: Bir Araştırma. İş, Güç Endüstri İlişkileri ve İnsan Kaynakları Dergisi, 2006; c.8, S.2, ss. 153-168.

7. Sevimli F, İşcan ÖF. Bireysel ve İş Ortamına Ait Etkenler Açısından İş Doyumu. 2005 Ege Akademik Bakış, 5(1):55-64.

8. Derin N. Devlet Hastanelerinde Çalışan Sağlık Personelinin İş Doyum Düzeyleri ve Etkileyen Faktörler Eskişehir Osmangazi Üniversitesi Sağlık Bilimleri Enstitüsü Hemşirelik Anabilim Dalı Psikiyatri Hemşireliği Bilim Dalı Yüksek Lisans Tezi. 2007.

9. Erşan $\mathrm{S}$ ve Sezgin A. Hemsirelerin iş doyum düzeyini etkileyen faktörler, İnönü Üniversitesi Sağlı Hizmetleri Meslek Yüksek Okulu Dergisi, 1998;4:4:71-78.

10. Engin E. Ege Üniversitesi Tıp Fakültesi Hastanesi yoğun bakım hemşirelerinin uyku düzen özellikleri ile iş doyumu arasındaki ilişkinin incelenmesi, Ege Üniversitesi Sağlık Bilimleri Enstitüsü Yayınlanmamış Yüksek Lisans Tezi. 1999; İzmir.

11. Road HC, Hsiang TH. The influence of nurses' working motivation and job satisfaction on itention to quit : an empirical investigation in taiwan, international Journal of Nursing Studies, 2002; 39: 867-878.

12. Lu H, While EA, Barriball LK. Job satisfaction among nurses: a litarature reviw, İnternational Journal of Nursing Studies, 2005; 42: 211-227.

13. Güneş N. Bir üniversite hastanesinde çalışan hemşirelerin iş doyumlarını etkileyen etmenlerin incelenmesi, Dokuz Eylül Üniversitesi Sağlık Bilimleri Enstitüsü Hemşirelikte Yönetim Programı Yüksek Lisans Tezi, 2007; İzmir.

14. Soyer A. Stres ve İş. Toplum ve Hekim Dergisi, 1999;14:108 $-114$.

15. Emiroğlu N . Çalışma Ortamı ve Ruh Sağlığı. Çınar Dergisi, 1999;2(2): 31-33.

16. Eğinli AT. Çalışanlarda İş Doyumu: Kamu ve Özel Sektör Çalışanlarının İş Doyumuna Yönelik Bir Araştırma. Atatürk Üniversitesi İktisadi ve İdari Bilimler Dergisi, 2009; 23.

17. Tüzün MB. Çalışanların İş Memnuniyetlerindeki Yetersizliklerin İşe Olumsuz Etkileri ve Bunun Saptanması İçin Bir Ölçek Gelistirme, İstanbul Üniversitesi Sosyal Bilimler Enstitüsü Yayımlanmamış Yüksek Lisans Tezi. 2002; İstanbul.

18. Finn CP . Autonomy: An İmportant Component For Nurses' Job Satisfaction International Journal Of Nursing Studies 2001; $38: 349-357$.

19. Fung-Kam L. Job Satisfaction and Autonomy Of Hong Kong Registered Nurses. Journal of Advanced Nursing, 1998; 27, 355-363. 
20. İpek H. Bir Üniversite Hastanesinde Çalışan Hemsirelerin İş Doyumu ve Denetim Odakları Arasındaki İlişkinin İncelenmesi, Hacettepe Üniversitesi Sağlı Bilimleri Enstitüsü Yayımlanmamış Bilim Uzmanlığı Tezi. 2003; Ankara.

21. Aşt1 N. İstanbul Üniversitesi araştırma ve uygulama hastanelerinde çalışan hemşirelerin iş günü kaybı, nedenleri, sıklığı ve iş doyumu ilişsisi. Doktora Tezi, İ.Ü.Sağlık Bilimleri Enstitüsü, 1993; İstanbul.
22. Yüksel, İhsan. Hemşirelerin iş tatmin düzeylerini ayırt edici iş tatmin öğelerinin diskriminant analiziyle belirlenmesi. Kocaeli Üniversitesi Sosyal Bilimler Enstitüsü Dergisi. 2002; 3/1: 67-78

23. Özkaya MO, Yakın V, Ekinci T. Stres düzeylerinin çalışanların iş doyumu üzerine etkisi. Celal Bayar Üniversitesi Çalışanları Üzerine Ampirik Bir Araştırma, Yönetim ve Ekonomi. 2008; 15(1): 163-180.

24. Nur D. Kamu hastanelerinde çalışan sağlik personelinin iş doyumu ve stres ilişkisi, Klinik Psikiyatri ; 2011; 14:230-24. 
